\title{
Pengaruh Minat dan Motivasi Belajar Siswa terhadap Prestasi Belajar Bahasa Indonesia
}

\author{
Sri Anisa \\ Fakultas Pascasarjana, Universitas Indraprasta PGRI \\ Jalan Nangka No. 58 C/TB. Simatupang, Tanjung Barat, \\ Jakarta Selatan 12530 \\ sri.anisa1993@gmail.com
}

\begin{abstract}
The purpose of this research is to know: 1) The influence of student's interest and motivation together to the result of Indonesian learning achievement. 2) The influence of student's learning interest to Indonesian learning achievement. 3) The influence of students' learning motivation on Indonesian language learning achievement. This research was conducted on the students of class $X$ SMK Swasta in Indramayu District. Student research respondents amounted to 78 Students. The research used was the survey by using correlation and regression analysis technique. Sampling in this research is using multistage random sampling technique. The results of research: 1) There is a significant influence of learning interest and motivation of learning together towards the achievement of learning Indonesian Vocational High School students in Indramayu District. This is evidenced by the acquisition of Sig value. $0.000<0,05$ and Fh= 15,247.2) There is a significant influence of learning interest to the achievement learn Indonesian Language Private Vocational students in Indramayu District. This is evidenced by the acquisition of Sig value. 0,000 $<0.05$ and the $=3.733$. 3) There is a significant influence on learning motivation in Indonesian language learning achievement of private vocational students in Indramayu District. This is evidenced by the acquisition of Sig value. $0.015<0.05$ and the = 2.498 .
\end{abstract}

Keywords: Influence of student's interest and motivation, learning achievement, Bahasa Indonesia.

\begin{abstract}
Abstrak
Tujuan dari penelitian adalah untuk mengetahui: 1) Pengaruh minat dan motivasi belajar siswa secara bersama-sama terhadap hasil prestasi belajar Bahasa Indonesia.2) Pengaruh minat belajar siswa terhadap prestasi belajar Bahasa Indonesia. 3) Pengaruh motivasi belajar siswa terhadap prestasi belajar Bahasa Indonesia. Penelitian ini dilaksanakan pada siswa kelas X SMK Swasta di Kabupaten Indramayu. Responden penelitian siswa berjumlah 78 Siswa. Penelitian yang digunakan adalah survei dengan menggunakan teknik analisis korelasional dan regresi. Sampel diambil dengan teknik multistage random sampling. Hasil penelitian : 1) Terdapat pengaruh yang signifikan minat belajar dan motivasi belajar secara bersama-sama terhadap prestasi belajar Bahasa Indonesia siswa SMK Swasta di Kabupaten Indramayu. Hal ini dibuktikan dengan perolehan nilai Sig. 0,000 $<0,05$ dan $\mathrm{Fh}=15,247.2$ )Terdapat pengaruh yang signifikan minat belajar terhadap prestasi belajar Bahasa Indonesia siswa SMK Swasta di Kabupaten Indramayu. Hal ini dibuktikan dengan perolehan nilai Sig. $0,000<0,05$ dan th $=$ 3,733. 3)Terdapat pengaruh yang signifikan motivasi belajar terhadap prestasi belajar Bahasa Indonesia siswa SMK Swasta di Kabupaten Indramayu. Hal ini dibuktikan dengan perolehan nilai Sig. 0,015 < 0,05 dan th $=2,498$.
\end{abstract}

Kata kunci: Pengaruh minat dan motivasi belajar siswa, prestasi belajar, Bahasa Indonesia.

\section{PENDAHULUAN}

Motivasi bagian penting dari proses belajar. Motivasi yang kuat dalam diri siswa akan meningkatkan minat kemauan dan semangat yang tinggi dalam belajar, karena antara motivasi dan semangat belajar mempunyai hubungan yang erat.

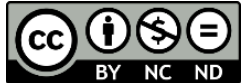


Melalui motivasi belajar, tujuan yang dikehendaki oleh subjek itu dapat tercapai (Sardiman A.M., 1986: 75).

Motivasi erat kaitannya dengan minat. Timbulnya motivasi disebabkan dengan adanya minat terhadap sesuatu atau kegiatan tertentu, dan motivasi yang timbul apabila disebabkan adanya minat dalam diri seeorang akan menjadi motivasi yang baik arah dan tujuanya. Tinggi rendahnya prestasi belajar seseorang dipengaruhi oleh berbagai faktor. Selain faktor guru, kurikulum dan faktor lain yang terletak di luar diri siswa, terdapat dua faktor penting yang terletak secara internal di dalam diri siswa sendiri yaitu faktor intelektif dan nonintelektif (Munandar, 2001: 76).

Motivasi sangat berperan dalam belajar. Tingginya motivasi dalam belajar berhubungan dengan tingginya prestasi belajar. Motivasi belajar siswa juga memiliki berbagai macam tingkatan. Seorang siswa yang sekolah memiliki motivasi belajar yang tinggi akan rajin mengerjakan segala tugas yang dibebankan kepadanya. Siswa juga akan rajin belajar untuk mengulang semua materi pelajaran yang diberikanya, sehingga pada akhirnya akan mampu mengerjakan soal ujian yang berakibat pada perolehan prestasi yang tinggi pula. Seorang siswa yang memiliki motivasi yang rendah akan malas untuk belajar sehingga akan berpengaruh terhadap prestasi belajarnya. Lingkungan keluarga juga mempunyai hubungan yang erat, terutama yang berkaitan dengan upaya pemotivasian siswa dalam belajar. Keluarga merupakan lembaga pendidikan utama yang berada di luar sekolah yang memberikan andil utama dan mendasar di dalam pembentukan sikap, kepribadian dan kebiasaan.

Dalam belajar siswa juga perlu disiplin, seperti jadwal belajar yang telah dibuatnya dan menaati peraturan sekolah. Ketaatan siswa terhadap aturan merupakan kesadaran diri untuk menaatinya dengan rasa senang dan tanggung jawab karena itu disiplin merupakan faktor yang berasal dalam diri (internal), bukan sebuah paksaan untuk mengikuti aturan. Seseorang tergerak hatinya untuk mengikuti aturan-aturan atau norma, dan ia sendiri merasa bahwa dirinya perlu untuk mengikuti aturan agar tujuan dapat tercapai. Masalah disiplin juga dihadapi guru dan orang tua dalam menghadapi remaja.

Usia remaja menurut Hurlock (1995: 53) ada pada rentang usia 11 atau 13 tahun sampai usia 21 tahun. Masa remaja yang merupakan masa transisi dari anak-anak menuju dewasa, ditandai dengan perubahan fisik, sikap, minat dan pola prilaku. Mereka berada pada masa mencari identitas, meningkatnya emosi dan pengaruh teman sebaya yang lebih dominan dibandingkan pengaruh keluarga. Apabila remaja kurang mendapat bimbingan keagamaan dan berteman dengan kelompok yang kurang menghargai nilai-nilai agama, maka kondisi di atas akan memicu berkembangnya sikap dan perilaku remaja yang kurang baik, bahkan cenderung untuk berbuat kenakalan remaja. Karena itu untuk menanamkan kedisiplinan, mengendalikan emosi, agar remaja dapat belajar dengan tenang dan meraih kesuksesan dalam belajar perlu ditanamkan nilai-nilai agama dan memaknai ajaran agamanya.

Prestasi belajar adalah kemampuan yang dimiliki siswa setelah ia menerima pengalaman belajarnya. Individu yang belajar akan memperoleh prestasi dari apa yang telah dipelajari selama proses belajar itu. Prestasi belajar 
yang dimaksud dalam penelitian ini adalah nilai yang dapat dicapai oleh siswa dengan kemampuan maksimal setelah siswa tersebut mengikuti kegiatan pembelajaran kemudian pengukuran hasil belajar dalam bentuk tes akhir semester. Bentuk frustasi, kemarahan, tekanan, tegangan semuanya itu merupakan faktor pengganggu terhadap hasil akademik atau prestasi belajar. Beragamnya prestasi belajar di sekolah sangat menarik untuk dianalisis lebih mendalam mengenai latar belakangnya mengenai penyebabnya. Beberapa hal diantaranya yang mendukung prestasi belajar yang diharapkan di sekolah yaitu minat belajar dan motivasi belajar. Minat dan motivasi belajar adalah dua aspek yang berbeda tapi sangat berpengaruh besar pada prestasi belajar yang diharapkan di sekolah.

Prestasi dalam belajar merupakan dambaan bagi setiap orang tua terhadap anaknya. Prestasi yang baik tentu akan didapat dengan proses belajar yang baik juga. Belajar merupakan proses dari sesuatu yang belum biasa menjadi bisa, dari perilaku yang lama ke perilaku yang baru, dari pemahaman yang lama ke pemahaman yang baru.

Secara garis besar factor-faktor yang mempengaruhi belajar terbagi dua yakni faktor internal yaitu faktor yang terdapat dalam diri siswa. Dan eksternal yaitu faktor yang berada di luar siswa. faktor dari dalam diri (internal) menyangkut faktor jasmaniah seperti kesehatan jasmani, kesehatan pancaindra, faktor rohaniah atau psikologis individu seperti kesehatan psikis, kemampuan intelektual, sosial, psikomotor serta kondisi efektif individu. Sedangkan faktor di luar diri siswa (eksternal) meliputi lingkungan social dan non-sosial, seperti lingkungan keluarga dan lingkungan yang secara tidak langsung mempengaruhi siswa dalam belajar.

Banyak sekali faktor yang dapat mempengaruhi pencapaian prestasi belajar. Orang tua pun perlu untuk mengetahui apa saja faktor yang dapat mempengaruhi proses belajar pada anak mereka, sehingga orang tua dapat menengenali penyebab dan pendukung anak dalam berprestasi. Faktor-faktor yang perlu diperhatikan faktor dalam diri dan lingkungan (Djaali, 2008: 15). Dari sekian banyak hal yang harus diperhatikan, tentu tidak ada situasi $100 \%$ yang dapat dilakukan secara keseluruhan dan sempurna.

\section{METODE}

Penelitian ini memilih tempat penelitian di Sekolah Menengah Kejuruan (SMK) Swasta di Kabupaten Indramayu. Sekolah yang menjadi sampel responden yaitu SMK Pembangunan Tukdana, SMK Miftahul Jannah Lelea, dan SMK AnNur Sukagumiwang.

Penelitian ini dilaksanakan empat bulan yaitu mulai dari bulan Maret sampai Juni. Dalam kurun waktu tersebut sudah dilaksanakan penelitian dalam tiga tahap yaitu: Pengumpulan data, berupa penyebaran angket ke siswa dan pengambilan sampel dari guru. Pengelolahan data, berupa analisis data dan pengujian hipotesis secara statistik. Penarikan kesimpulan, termasuk penuangan ke dalam laporan tertulis.

Metode yang digunakan dalam penelitian ini adalah metode survei dengan teknik koresional. Variabel penelitain ini terdiri dari variabel terikat (dependent variable), yaitu hasil belajar siswa pada mata pelajaran Bahasa Indonesia (Y) 
Minat Belajar (X1), Motivasi Belajar(X2). Arikunto (2010:180) menyatakan bahwa, "populasi adalah keseluruhan subjek penelitian." Menurut Sugiono (2010: 117)," populasi adalah wilayah generalisasi yang terdiri objek/subjek yang mempunyai kualitas dan karakterisitik tertentu". Sabar (2007) populasi adalah keseluruhan subyek penelitian. Populasi dalam penelitian ini adalah seluruh siswa kelas X SMK Pembangunan Tukdana, SMK Miftahul Jannah Lelea dan SMK AnNur Sukagumiwang dengan jumlah 78 siswa, tahun pelajaran 2017/2018.

Teknik pemilihan sampel dalam penelitian ini menggunakan teknik random. Tekinik random digunakan dalam memilih anggota sampel responden jumlah anggota sampel responden dalam penelitian ini ditetapkan sebanyak 100 siswa. Pengambilan sampel responden dipilih secara acak.

Instrumen yang digunakan untuk mengumpulkan data tentang minat belajar berbentuk kuesioner dengan menggunakan rating scale. Model rating scale yang digunakan dalam bentuk kontinum dengan 5 (lima) kategori, yaitu nilai jawaban selalu $=5$, sering $=4$, kadang-kadang $=3$, pernah $=2$, dan tidak pernah $=$ 1. Semua pertanyaan diatur sedemikian rupa semua bermakna positif.

Kuesioner motivasi belajar ini yang disusun dalam 40 butir pertanyaan yang selanjutnya diuji validitas butir dan reliabilitas instrumen sehingga layak digunakan sebagai instrumen penelitian. Langkah selanjutnya adalah disampaikan pada responden.

\section{HASIL DAN PEMBAHASAN}

\section{Hasil}

Data prestasi belajar Bahasa Indonesia diperoleh dari nilai tes 78 siswa yang menjadi sampel penelitian. Nilai yang diperoleh adalah terendah 63, tertinggi 98, rata-rata sebesar 81.29, median sebesar 83.00, modus sebesar 93 dan simpangan baku sebesar 10.907. Bila dilihat dari hasil perhitungan, dapat dikatakan bahwa prestasi belajar Bahasa Indonesia siswa SMK Swasta di Kabupaten Indramayu tergolong tinggi. Hal ini diindikasikan dengan perolehan skor rata-rata sebesar 81.29. Untuk memperjelas data di atas, digambarkan dalam histogram sebagai berikut:

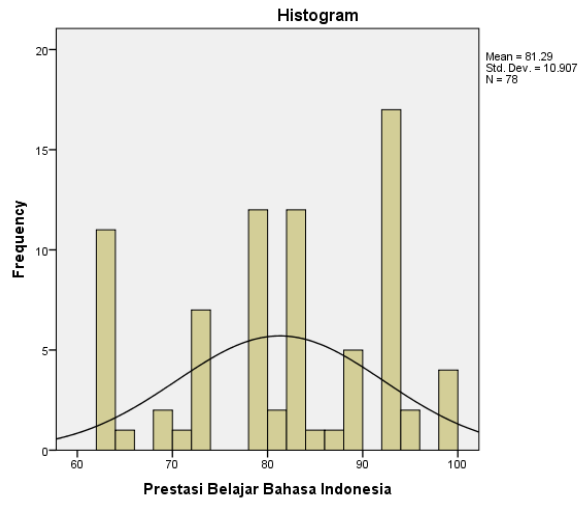

\section{Gambar 1. Histogram Poligon Variabel Prestasi Belajar Bahasa} Indonesia 
Dari histogram dan polygon frekuensi di atas dapat disimpulkan bahwa data prestasi belajar Bahasa Indonesia siswa SMK Swasta di Kabupaten Indramayu memiliki sebaran yang normal.

Data minat belajar diperoleh dari skor kuesioner yang dijawab oleh 78 siswa dihasilkan skor terendah 103, skor tertinggi 133, skor rerata sebesar 119.41, median 118.00, modus sebesar 113, dan simpangan baku sebesar 8.524. Dari hasil perhitungan, dapat dikatakan bahwa minat belajar siswa SMK Swasta di Kabupaten Indramayu tinggi. Hal ini diindikasikan dengan perolehan skor rerata sebesar 119.41. Untuk memperjelas data di atas, digambarkan dalam histogram sebagai berikut:

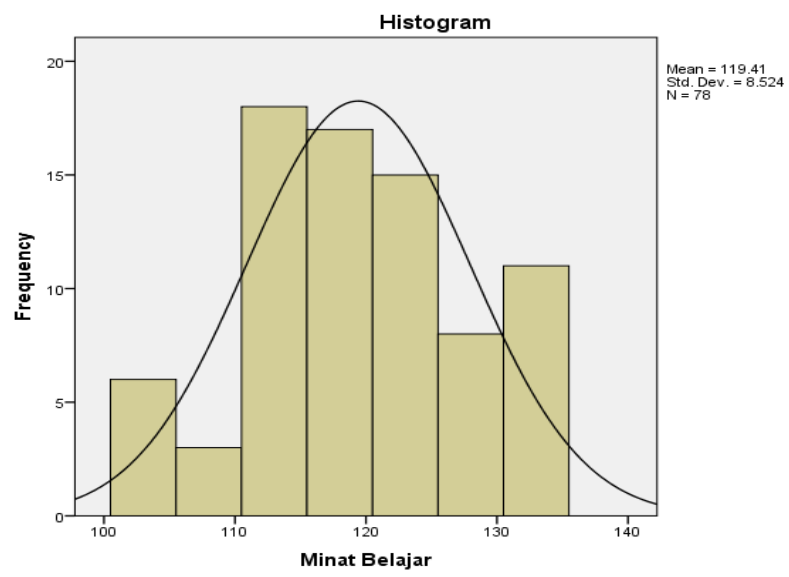

Gambar 2. Histogram Poligon Variabel Minat Belajar

Dari histogram dan polygon frekuensi di atas dapat disimpulkan bahwa minat belajar siswa SMK Swasta di Kabupaten Indramayu memiliki sebaran yang normal. Data motivasi belajar diperoleh dari skor kuesioner yang dijawab oleh 78 siswa sebagai responden dihasilkan nilai terendah 99, nilai tertinggi 129 , nilai rerata sebesar 114.03, median sebesar 114.00, modus sebesar 114 dan simpangan baku sebesar 8.485. Dari hasil perhitungan, maka bisa dikatakan bahwa motivasi belajar siswa SMK Swasta di Kabupaten Indramayu tinggi. Hal ini diindikasikan dengan perolehan nilai rerata skor motivasi belajar 114.03. Untuk memperjelas data di atas, digambarkan dalam histogram sebagai berikut:

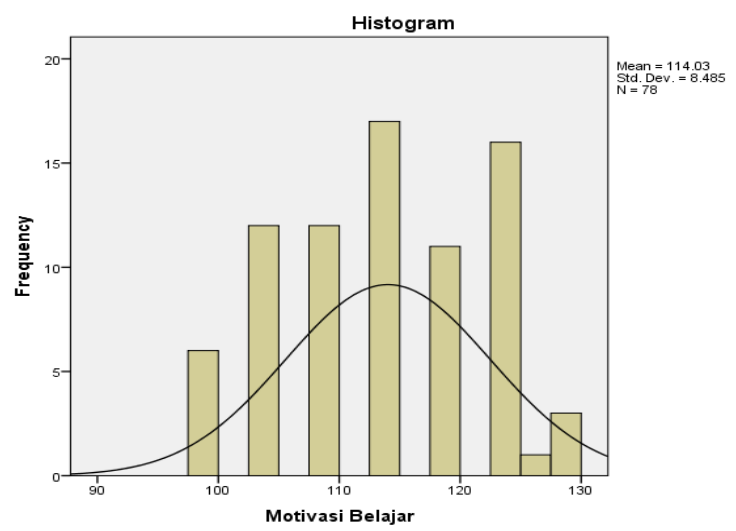

Gambar 3. Histogram Poligon Variabel Motivasi Belajar 
Diskursus: Jurnal Pendidikan Bahasa Indonesia

Vol. 1, No. 1, April 2018, pp. 109-118

p-ISSN: $2615-4935$

e-ISSN: 2615-4943

Dari histogram dan polygon frekuensi di atas dapat disimpulkan bahwa motivasi belajar siswa SMK Swasta di Kabupaten Indramayu memiliki sebaran yang normal.

\section{Linaeritas Regresi Pengaruh Variabel $\mathrm{X}_{1}$ atas $\mathrm{Y}$}

Hasil uji linearitas regresi antara minat belajar dengan prestasi belajar Bahasa Indonesia, perhitungan SPSS 20.0 sebagai berikut:

Tabel 1. Hasil Pengujian Linearitas Regresi Variabel $\mathrm{Y}$ atas $\mathrm{X}_{1}$

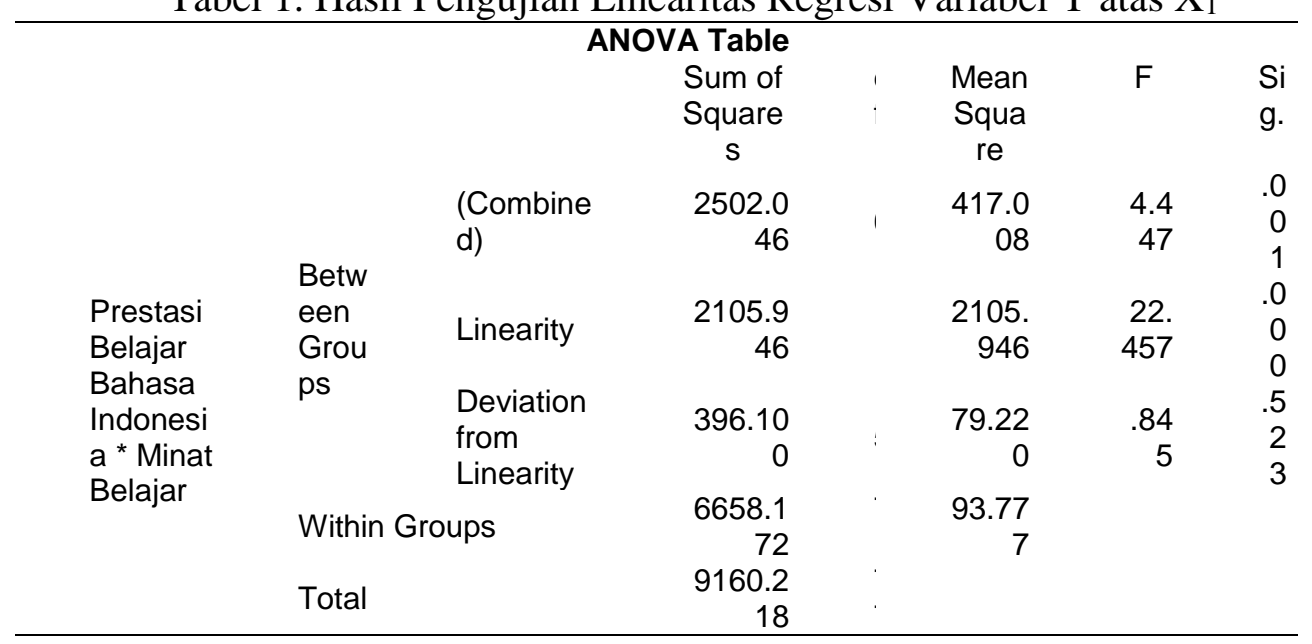

Berdasarkan hasil perhiungan di atas diperoleh hasil perhitungan Deviation from Linearity dengan $\mathrm{Fo}=0,845$ dan Sig. $=0,523>0,05$. Hal ini memiliki pengertian bahwa variabel minat belajar dengan prestasi belajar Bahasa Indonesia siswa mempunyai mempunyai hubungan yang linear.

\section{Linaeritas Regresi pengaruh variabel $\mathbf{X}_{2}$ atas $\mathbf{Y}$}

Hasil uji linearitas regresi antara motivasi belajar dengan prestasi belajar Bahasa Indonesia, perhitungan SPSS 20.0 sebagai berikut:

Tabel 2. Hasil Pengujian Linearitas Regresi Variabel $\mathrm{Y}$ atas $\mathrm{X}_{2}$

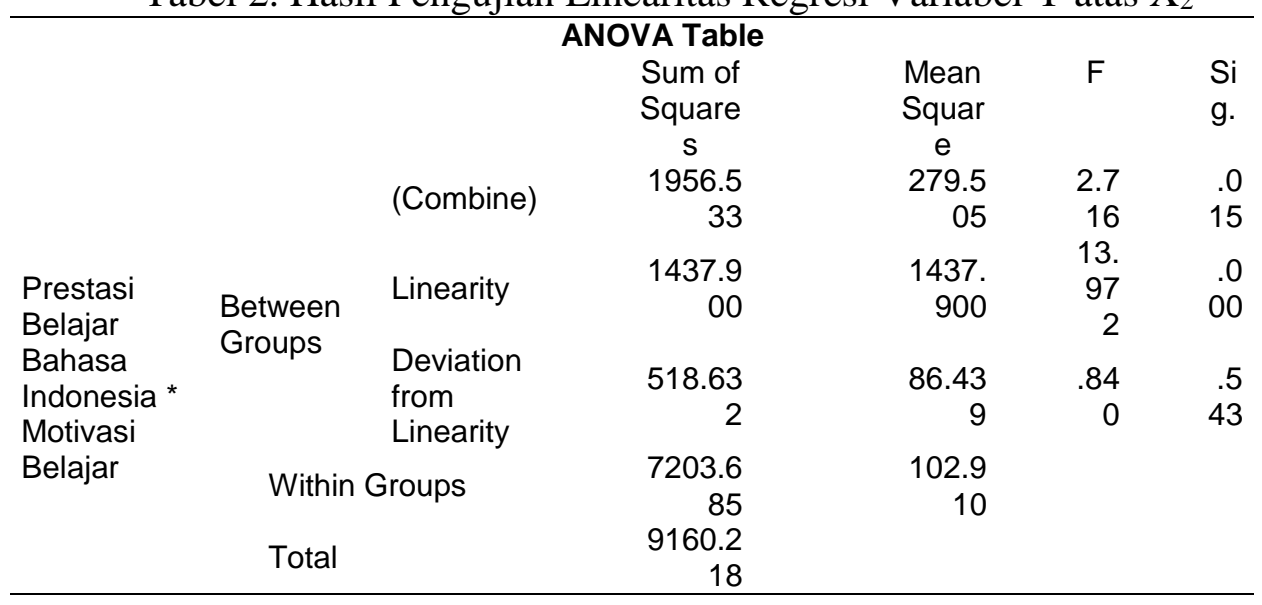


Diskursus: Jurnal Pendidikan Bahasa Indonesia

Vol. 1, No. 1, April 2018, pp. 109-118

p-ISSN: $2615-4935$

e-ISSN: 2615-4943

Berdasarkan hasil perhitungan di atas diperoleh hasil Deviation from Linearity dengan Fo $=0,840$ dan Sig. $=0,543>0,05$. Hal ini memiliki pengertian bahwa variabel motivasi belajar dengan prestasi belajar Bahasa Indonesia siswa mempunyai mempunyai hubungan yang linear.

\section{Pengujian Hipotesis}

Pengajuan hipotesis dilakukan sesuai dengan ketentuan yang telah dijelaskan dalam Bab III. Hasil perhitungan dan pengujian bisa dilihat pada tabel di bawah ini:

Tabel 3. Hasil Perhitungan Pengujian Koefisien Korelasi Ganda

\begin{tabular}{|c|c|c|c|c|}
\hline \multicolumn{5}{|c|}{ Variabel $X_{1}$ dan $X_{2}$ terhadap $Y$} \\
\hline $\begin{array}{l}\text { Mod } \\
\text { el }\end{array}$ & $\mathrm{R}$ & $\begin{array}{c}\mathrm{R} \\
\text { Square }\end{array}$ & $\begin{array}{l}\text { Adjusted R } \\
\text { Square }\end{array}$ & $\begin{array}{l}\text { Std. Error of } \\
\text { the Estimate }\end{array}$ \\
\hline 1 & $\begin{array}{l}5 \\
3 \\
8 \\
a\end{array}$ & .289 & .270 & 9.318 \\
\hline
\end{tabular}

a. Predictors: (Constant), Motivasi Belajar, Minat Belajar

Tabel 4. Hasil Perhitungan Pengujian Signifikansi Koefisien

$$
\text { Regresi }
$$

Variabel $\mathrm{X}_{1}$ dan $\mathrm{X}_{2}$ terhadap $\mathrm{Y}$

\begin{tabular}{|c|c|c|c|c|c|c|}
\hline \multicolumn{7}{|c|}{ ANOVA $^{a}$} \\
\hline \multicolumn{2}{|c|}{ Model } & Sum of & I & Mean & $\mathrm{F}$ & $S$ \\
\hline \multirow{3}{*}{1} & $\begin{array}{l}\text { Regres } \\
\text { sion }\end{array}$ & 2647.787 & $\vdots$ & 1323.894 & $\begin{array}{r}15 \\
.2 \\
47\end{array}$ & $\begin{array}{l}0 \\
0 \\
0\end{array}$ \\
\hline & $\begin{array}{l}\text { Residu } \\
\text { al }\end{array}$ & 6512.431 & ? & 86.832 & & \\
\hline & Total & 9160.218 & . & & & \\
\hline
\end{tabular}

a. Dependent Variable: Prestasi Belajar Bahasa Indonesia

b. Predictors: (Constant), Motivasi Belajar, Minat Belajar

Tabel 5. Hasil Perhitungan Persamaan Regresi Ganda Variabel $\mathrm{X}_{1}$ dan $\mathrm{X}_{2}$

\begin{tabular}{|c|c|c|c|c|c|}
\hline \multicolumn{6}{|c|}{ Coefficients $^{a}$} \\
\hline \multirow[t]{2}{*}{ Model } & \multicolumn{2}{|c|}{$\begin{array}{l}\text { Unstandardized } \\
\text { Coefficients }\end{array}$} & \multirow{2}{*}{$\begin{array}{c}\text { Standardiz } \\
\text { ed } \\
\text { Coefficients } \\
\text { Beta }\end{array}$} & \multirow[t]{2}{*}{$\mathrm{t}$} & $\begin{array}{l}\mathrm{S} \\
\mathrm{i}\end{array}$ \\
\hline & B & $\begin{array}{l}\text { Std. } \\
\text { Error }\end{array}$ & & & \\
\hline (Constant) & $\begin{array}{r}- \\
16.09 \\
3\end{array}$ & $\begin{array}{r}17.76 \\
8\end{array}$ & & $\begin{array}{r}- \\
.9 \\
06\end{array}$ & $\begin{array}{l}3 \\
6\end{array}$ \\
\hline $\begin{array}{l}\text { Minat } \\
\text { Belajar }\end{array}$ & .497 & .133 & .388 & $\begin{array}{r}3 . \\
73 \\
3\end{array}$ & $\begin{array}{l}0 \\
0 \\
0\end{array}$ \\
\hline
\end{tabular}


Diskursus: Jurnal Pendidikan Bahasa Indonesia

Vol. 1, No. 1, April 2018, pp. 109-118

p-ISSN: 2615-4935

e-ISSN: $2615-4943$

$\begin{array}{llllrl}\text { Motivasi } & & & & 2 . & 0 \\ \text { Belajar } & .334 & .134 & .260 & 49 & 0 \\ & & & 8 & 5\end{array}$

a. Dependent Variable: Prestasi Belajar Bahasa Indonesia

\section{Pembahasan \\ Pengaruh pengaruh minat belajar (X1) dan motivasi belajar (X2) secara bersama-sama terhadap prestasi belajar Bahasa Indonesia (Y)}

Hasil penelitian di atas menyimpulkan bahwa minat belajarmotivasi belajar secara bersama-sama telah memberikan pengaruh positif terhadap peningkatan prestasi belajar Bahasa Indonesia siswa SMK Swasta di Kabupaten Indramayu. Hal ini mengandung arti bahwa minat belajar dan motivasi belajar telah memberikan pengaruh yang signifikan terhadap peningkatan prestasi belajar Bahasa Indonesia siswa SMK Swasta di Kabupaten Indramayu.

Menurut sintesis teori yang ada, motivasi belajar merupakan proses dimana dengan kehadirannya aktivitas individu yang mengarah ke tujuan dan mengatasi rintangan dapat dikuatkan dan berlangsung terus. Minat adalah kecenderungan yang tetap untuk memperhatikan dan mengenang beberapa kegiatan. Kegiatan yang diminati seseorang, diperhatikan terus menerus yang disertai dengan rasa senang. Jadi berbeda dengan perhatian karena perhatian sifatnya sementara (tidak dalam waktu yang lama) dan belum tentu diikuti dengan perasaan sehingga diperoleh dengan kesenangan.

Hasil belajar Bahasa Indonesia adalah tingkat pencapaian kemampuan pengetahuan siswa pada materi Bahasa Indonesia serta pencapaian keterampilan dan sikap yang terkait dengan wawasan Bahasa Indonesia. Secara operasional hasil belajar diukur melalui tes dan dengan tes tersebut siswa dituntut untuk menyelesaikan soal-soal yang dihadapi. Siswa yang motivasi belajarnya tinggi, memiliki inisiatif untuk melakukan kegiatan berprestasi, bekerja sama dengan intensitas tinggi, sabar dalam menghadapi kegagalan dan memilih tugas yang taraf kesulitannya sedang. Siswa yang mengandalkan usaha dan kemampuan untuk mencapai tujuan maka dia akan bangga akan keberhasilannya. Rasa penghargaan yang tinggi terhadap diri sendiri ini meningkatkan keinginan mereka berinisiatif pada langkah-langkah berprestasi berikutnya, dan cenderung ingin melakukan hal yang berharga ini. Sedangkan siswa yang memiliki motivasi berprestasinya rendah karena mengandalkan faktor eksternal daripada internal maka harga diri mereka tidak tinggi dan tidak memiliki inisiatif untuk berprestasi.

Selain motivasi belajar, dalam rangka meningkatkan prestasi belajar Bahasa Indonesia, perlu minat belajar yang tinggi, yang dapat memberikan pengaruh yang berarti terhadap prestasi belajar Bahasa Indonesia yang ditandai dengan keikutsertaan siswa dalam pembelajaran dan hasil ujian yang memuaskan. Dengan disiplin dan konsentrasi yang tinggi dalam belajar maka niscaya akan diperoleh prestasi belajar yang tiinggi. Semakin tinggi usaha seseorang untuk meningkatkan atau mempertahankan setinggi mungkin kecakapan yang dimiliki untuk mecapai tujuan maka akan ada hasil atau tujuan yang dicapai pun akan 
maksimal. Demikian juga dalam belajar, semakin tinggi usaha seseorang dalam belajar niscaya akan diperoleh prestasi belajar yang tinggi.

Dari informasi kuantitatif dan teori tersebut maka peneliti memperoleh kesimpulan bahwa terdapat pengaruh positif dan signifikan motivasi dan minat belajar siswa secara bersama-sama terhadap prestasi belajar Bahasa Indonesia.

\section{Pengaruh minat belajar (X1) terhadap prestasi belajar Bahasa Indonesia} (Y).

Hasil penelitian di atas menyimpulkan bahwa minat belajartelah memberikan pengaruh positif terhadap peningkatan prestasi belajar Bahasa Indonesia siswa SMK Swasta di Kota Indramayu. Hal ini mengandung arti bahwa minat belajar, siswa memberikan pengaruh yang cukup signifikan terhadap peningkatan prestasi belajar Bahasa Indonesia siswa SMK Swasta di Kota Indramayu.

Menurut sintesis teori, minat sangat besar pengaruhnya terhadap hasil belajar karena apabila bahan pelajaran yang dipelajari tidak sesuai dengan minat, siswa tidak akan belajar dengan baik sebab tidak menarik baginya. Siswa akan malas belajar dan tidak akan mendapatkan kepuasan dari pelajaran itu. Bahan pelajaran yang menarik minat siswa, lebih mudah dipelajari sehingga dapat meningkatkan prestasi belajar. Dari informasi kuantitatif dan teori tersebut, maka peneliti mempunyai simpulan bahwa terdapat pengaruh signifikan minat belajar siswa terhadap prestasi belajar Bahasa Indonesia.

\section{Pengaruh Motivasi belajar (X2) terhadap Prestasi belajar Bahasa Indonesia (Y).}

Dari hasil penelitian dan teori yang ada dapat disimpulkan bahwa motivasi belajar telah memberikan pengaruh positif terhadap peningkatan prestasi belajar Bahasa Indonesia siswa SMK Swasta di Kota Indramayu. Artinya, motivasi belajar yang tinggi telah memberikan pengaruh yang signifikan terhadap peningkatan prestasi belajar Bahasa Indonesia siswa SMK Swasta di Kota Indramayu.

Menurut sintesis teori, motivasi belajar adalah sebagai usaha yang bertujuan untuk mencapai hasil dengan membandingkan beberapa keunggulan. Keunggulan disini merupakan perbandingan antara prestasi yang dicapai sendiri atau prestasi yang sudah dicapai sebelumnya. Seseorang yang telah memiliki motivasi berprestasi tidak akan merasa puas dengan prestasi belajar yang sudah diraihnya. Ia akan selalu membandingkan dengan hasil belajar siswa lain dalam satu kelas. Untuk memperoleh hasil yang baik dalam pendidikan, maka siswa yang ingin mempunyai hasil belajar yang tinggi akan berusaha untuk meningkatkan kemampuannya dengan sungguh-sungguh sebagai rasa tanggung jawabnya. Namun bila menemukan kesulitan dalam belajar, maka mereka akan berusaha dengan segala kemampuan yang dimiliki untuk mengatasi kesulitan tersebut.

Dari informasi kuantitatif dan teori tersebut maka peneliti mempunyai kesimpulan bahwa terdapat pengaruh positif dan signifikan motivasi berprestasi siswa terhadap prestasi belajar Bahasa Indonesia. 
Diskursus: Jurnal Pendidikan Bahasa Indonesia

Vol. 1, No. 1, April 2018, pp. 109-118

p-ISSN: 2615-4935

e-ISSN: 2615-4943

\section{SIMPULAN}

Berdasarkan penelitian yang telah dilakukan, dapat disimpulkan:

1. Terdapat pengaruh positif dan signifikan motivasi dan minat belajar siswa secara bersama-sama terhadap prestasi belajar Bahasa Indonesia.

2. Terdapat pengaruh signifikan minat belajar siswa terhadap prestasi belajar Bahasa Indonesia.

3. Terdapat pengaruh positif dan signifikan motivasi berprestasi siswa terhadap prestasi belajar Bahasa Indonesia.

\section{DAFTAR PUSTAKA}

Arikunto, Suharsimi. (2010). Dasar-dasar evaluasi pendidikan. Jakarta: Penerbit Bumi Aksara.

Djaali dan Muljono, P. (2008). Pengukuran dalam bidang pendidikan. Jakarta: Grasindo

Hurlock, E.B. (1995). Perkembangan anak. Jakarta: Erlangga .

Munandar. (2001). Ensiklopedia pendidikan. Malang: Universitas Malang Press.

Sabar. (2007). Populasi dan sampel penelitian. Diakses dari https://sugithewae.wordpress.com./

Sardiman. (1986). Interaksi dan motivasi belajar mengajar. Jakarta: Grafindo. 